\title{
ANALYSIS OF SOURCES AND LEVEL OF PENETRATION: APPLICATION OF FACTOR AND DISCRIMINANT ANALYSIS
}

\author{
M. Selvakumar, R. Mohammed Abubakkar Siddique and V. Sathyalakshmi \\ Department of Commerce (PG-R), Ayya Nadar Janaki Ammal College, India
}

\begin{abstract}
The present research work is undertaken to analyse the sources of penetration and level of penetration. A Source of penetration is defined by actions a firm takes to communicate with end users, consumers and external parties. It covers the five subsets, such as advertising, sales promotion, direct marketing, personal selling and public relations. In this study, the researcher has applied the factor analysis to analyze the customers' opinion towards the sources of penetration. In order to analyze the sources of penetration and level of penetration, the researcher has used discriminant analysis. The result reveals that $18.6 \%$ of variables predict the level of penetration. Moreover, Advertising and Direct Marketing are the most important sources that discriminates the level of penetration.
\end{abstract}

Keywords:

Advertising, Sales Promotion, Direct Marketing, Personal Selling, Public Relations

\section{INTRODUCTION}

The banking industry now characterized as technology enabled, lower cost, seamless payment, better customer experience and services to the people who excluded before. Now, the banks able to deliver all the services real time due to the internet and mobile connectivity [1].

In India, the rural people have faced the problem of lack of accessibility of most of the financial and banking products. $74 \%$ of the Indian population living in rural India and only $18 \%$ of the total banking penetration of India is in rural area [2]. As the low penetration in the rural market, rural financial services are ever growing segment in India. Today, only around $41 \%$ of rural households have formal savings accounts and $20 \%$ alone have access to credit from banking system [3].

Due to rapidly changing environment, today's banking operation is a highly competitive and plays a role in the development of rural areas and improvement in rural life. By and large, by assigning a responsible role on bank officials, the socio economic transformation of the rural society is concentrated.

To penetrate the banking operation, there is a need for total marketing approach from the banking personnel. Efforts to be made to design and launch suitably personalized services to meet its changing needs of the rural population. The bank official should be able to establish a whole link with rural masses in rural areas. They should be committed in rural upliftment and should implement the market strategies framed for the purpose.

The success of marketing strategy is based on the power of the branch and potential customers. There is a need to train the bank staff to deal with rural customers and also need for developing a sense of belonging towards the organization, customers and the society [4].
The marketing and distribution strategies of banks are different in urban and rural areas due to diverse demographic and socio economic nature of these markets. Private Sector Banks are mostly giving attention to urban areas due to high income, healthier infrastructure, higher investor etc. The distribution channels used by such banks include bank branches, ATMs, internet banking, mobile banking, direct selling agents, call centre etc.

Private sector banks are also penetrating into rural areas by using non-branch delivery systems like the Business Facilitator (BF) model and Business Correspondent (BC) Model proposed by RBI in 2006. Under the BF model, banks utilize the network of intermediaries such as NGOs, post offices for banking services such as creating awareness and educating on the financial products, collecting and processing of information of borrowers, selling banking products and financial services to rural households, etc. Intermediaries under these models have knowledge about the local population and provide feedback about the requirements of the local population [5].

Today, owing to the speedy growth of banking sector in the competitive market, demand for products and services often has a significant growth. Due to rapid changes in the status of the competitors, technology and the desires of customers, banking companies cannot always rely on their existing products. Banking customers looking for new and more advanced products and they forced to create new services that meet the needs and expectations. Sources of penetration refers to the successful selling of product or service in a specific market/customers, and it is measured by the amount of sales volume of an existing good or service compared to total target market for that product or service. It involves targeting on selling existing goods or services in the targeted markets/customers to increase the better value of a banking company.

\section{LITERATURE REVIEW}

In order to discover the research gap, the researcher has made an attempt to collect the subsequent review to have an approaching for the crisis. A small amount of related studies have been made on this pasture which are little to helpful to this research. A review of such study is presented below.

Puja Bansal and Vikas Behal [6] Banking plays a vital role in the growth and development of developing countries like India. Banks fluctuates the entire financial system and guarantee to smooth operations. With the commencement of the process of liberalization and globalization of the economy, the financial sector, principally the commercial banks, not only in urban areas, but also in rural areas were the first to experience the winds of change.

Anil Kumar Agarwal [7] analysed the banking penetration in rural areas and villages: trends and challenges. Based on the 
study, the author suggests some scenarios, which are consumer financial education awareness, consumer financial transaction databases, capitalization of Mutual Fund Investments, localized financial institutions and mobile based delivery model, which are the most probable in the year 2020 for the Indian rural retail banking industry. Moreover, the rural retail banking industry has the potential and the ability to rise to the occasion as demonstrated by the rapid pace of automation which had an impact on raising the standard of banking services.

Neeraj Kumar and Anoki [8] Regional rural banks in India penetrated every corner of the country and extended a helping hand in the growth process of the country. Capital share of RRBs being $50 \%$ by the central government, $15 \%$ by the state government and $35 \%$ by the scheduled bank. The renewed emphasis on agricultural and rural development by the Government of India would lead to a growing demand for different types of financial services in the rural areas.

Dhananjay Bapat [9] there is ample scope for further penetration by banks into rural areas and various avenues to market credit products to the customers. The reasons for the low credit intake by the rural people can stem from two major factors: the first one is the supply side and the second one is the demand side. The supply side can be due to the inertia or lack of initiative on the part of the bank staff in making an effort to extend facilities and/or due to the reduced interest on deposits offered by the bank. The demand side can be due to the lack of interest of customers for availing credit services from the bank on account of the demanding procedures involved.

Bhuvana and Vasanth [10] shows that the Reserve Bank of India (RBI) has acknowledged that financial inclusion is a practice of distribute a financial services at a fair cost to the rural inhabitants. The financial services such as on time credit facilities and easy to get a financial products and services like small saving deposits reach the rural people. Moreover, this study has considered the level of financial inclusion with the three diverse dimensions such as Branch Penetration of Banking Industries, Deposit Penetration and Credit Penetration in the rural areas of Tamil Nadu.

Assocham India [11] in Internet Penetration, usage model of internet has moved from the desk based usage and mobile has become the preferred model. The telecommunication revolution has shifted the gear towards usage of mobile phones for various applications. As per Assocham, India Report, April 2015, presently $74 \%$ of the population is using mobile phones for their personal use demonstrating the high penetration of mobile telephony in India.

The Times of India [12] in Mobile Banking Penetration, India stands at number 4 and in case of banking through mobile, youth in the average age group of about 30 are the key players and also the lowest among the worldwide banking customers. According to BI Intelligence [13] the visit to their banks branches is often becoming less than before. Another alternative channel ATMs which served as a relatively less costly channel for the bank as compared to the branch format, performed well but with the rapid traction in the non-cash transactions among the millennia's, Internet Banking and Mobile Banking are becoming the game changers in the channel paradigm of bank customers. That will make the smart phone as the primary channel for banking transactions.
According to KPMG Report [14] Mobile Banking user segment is growing at a rapid phase and expected to grow exponentially in the next 5 to 10 years and in developing countries, the adoption rates are going to be still higher. The adoption rates are in the range of 60 to $70 \%$ in India and China than in other developed countries like US and Canada. But the adoption rates within the individual countries are dissimilar. In India, Mobile Banking facility is offered by almost all commercial banks and mostly app based.

Sethuraman et al. [15] examined a study on channel preferences among urban and rural banking customers. Banks offers different channels for enhancing the experience of their customers. This study provides clues for banks to revisit their channel strategies and initiate effective action plans to enhance awareness and also bridge the awareness and usage and that will help them for developing channel matrix for achieving the optimal transactions costs of servicing the customers. The important finding from the study is awareness level does not readily translate into usage of those channels, so the banks whether the channel offerings are really reaching customers across rural, semi urban and urban bank customers and translate into usage more than the awareness.

Apurva Singh [16] analysed the E-Banking in Sub-urban India. In this study, the author focused on assessing the customer's perception about e-banking of in sub-urban India and determining the factors that drive customer towards better perception. This study would be useful for policy makers and bank managers in the formulation of best practice in order to promote e-banking services.

Bhavesh J. Parmar, et al. [17] investigated the rural banking through internet: a study on use of internet banking among rural consumers. This study discusses development of internet banking in rural areas and to consider the opportunity of using internet banking in the new generation of rural area. As a final point the author wrap up, the concept and technology are new to the rural consumer in recent years, mostly people are using nearer to one year. Expectations of consumers towards internet banking are it should be time saving and convenient to use, should be user friendly and best in security.

Cleland F. Afful, et al. [18] highlighted the rural banking in Ghana and its impact on rural farmers. In this study, the author examines the impact of financial institutions, especially rural banks on rural farmers. The paper shows that the rural bank has a positive impact on the people in terms of giving such as poverty alleviation and food security and financial advisory services. In conclusion for rural banks to make a significant impact in agricultural development and the bigger picture of improving the food security of the rural farmer, emphasis should be placed on more education for the farmers on the use of the credit.

Peter John [19] studied the mobile banking products and rural India: an evaluation. The implementation of financial sector reforms the process of computerization in the banking industry significantly changed the structure and texture of urban and metropolitan economy. Now, it is the need of the time for concern and commitment to create enabling environment for application of m-banking technology in rural India to erase the rural-urban divide and integrate rural economy with global economy. 


\section{THEORETICAL MODEL FRAMEWORK}

With the help of theoretical background the researcher has framed the model for sources of penetration. The model for sources of penetration is given as Fig.1.

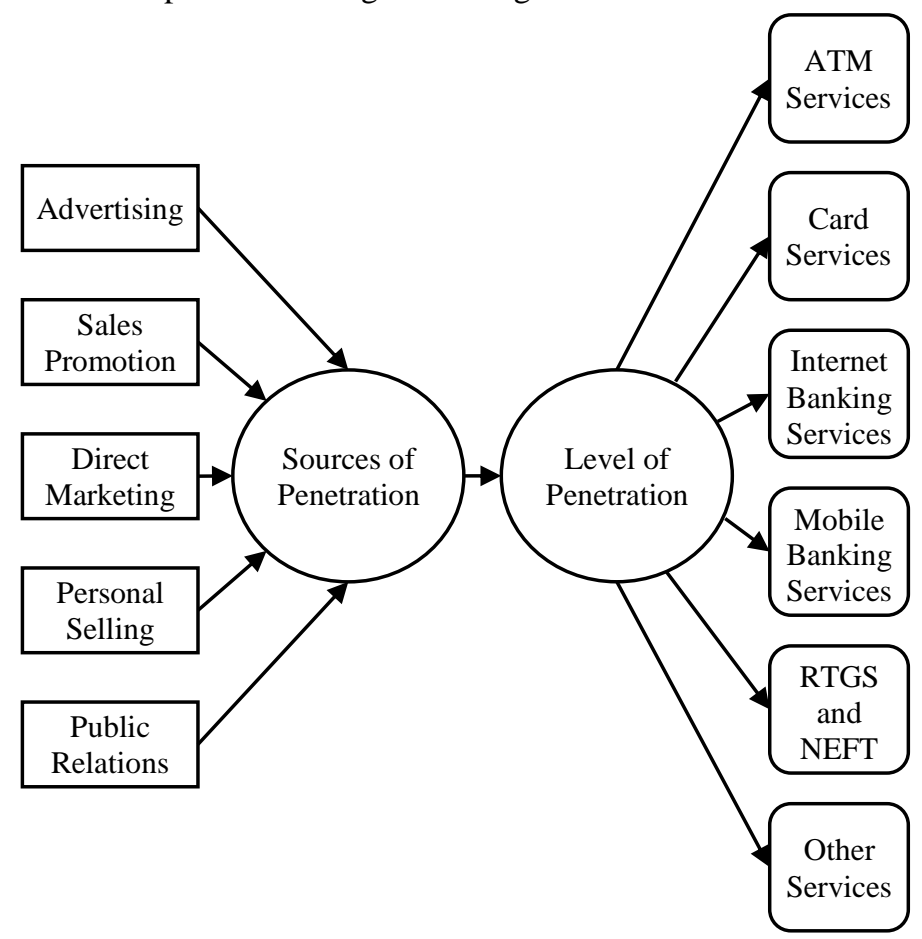

Fig.1. Relationship between Sources and Level of Penetration

Based on the above theoretical model, to analyse the sources and level of penetration of banking services, the factor analysis has been applied. To study relationship between sources and level of penetration, the researcher has applied discriminant analysis.

\section{OBJECTIVES OF THE STUDY}

The objectives have been framed by the researcher

- To analyse the customers opinion towards sources of penetration.

- To examine the source of penetration and level of penetration.

- To suggest measures that help in improving the banking services in rural areas.

\section{RESEARCH METHODOLOGY}

As the main purpose of the study is to identify, the sources which penetrates the banking services, the researcher collect the information and gain the knowledge on the sources of penetration of banking services from the previous studies on the basis of the knowledge gained, the researcher identifies the major sources such as advertising, sales promotion, direct marketing, personal selling and public relation.

Moreover, to determine the level of penetration, the measuring variables are ATM services, card services, internet banking, mobile banking, RTGS \& NEFT and other banking services have been identified by the researcher and have framed the model for the sources and level of penetration. Therefore the opinion of respondents about the sources has been collected from the sample respondents of the study area.

The present research work is analytical and descriptive nature. A pre-test was conducted on $10 \%$ of the sample respondents. Some modifications, additions, and deletion of questions are made according to the results of pre-test and suggestions of subject experts. Then the final study was conducted on a sample of 200 respondents in the Sivakasi rural areas.

The researcher has used convenience sampling method to select the sample respondents. The questionnaire has developed for the study was personally administrated to 200 sample respondents in the month of January 2016 to March 2016. Questions were prepared using likert five point scaling technique. Percentage analysis, factor analysis and discriminant analysis were used for analyzing the responses.

\section{RESULTS AND DISCUSSION}

\subsection{OPINION OF CUSTOMERS TOWARDS THE SOURCES OF PENETRATION}

In this survey, the researcher has analyzed the opinion of customers towards the various sources of penetration such as Advertising, Sales Promotion, Direct Marketing, Personal Selling and Public Relations. The views are gathered through Likert five point scale scaling technique. The researcher has assigned five points for "Strongly Agree", four points for "Agree", three points for "No Opinion", two points for "Disagree" and one point for "Strongly Disagree". The following Table shows the opinion of customers towards the sources of penetration.

\subsubsection{Opinion Regarding Advertising:}

Advertising plays a vital role in attracting the customers nowa-days. Advertising influences the people for using the products and services offered by the banks. Hence, the researcher has collected details regarding the opinion of the respondents towards the advertising and it is revealed in the Table.1.

Table.1. Opinion Regarding Advertising

\begin{tabular}{|c|c|c|c|c|c|}
\hline Statements & $\begin{array}{c}\text { Strongly } \\
\text { Agree }\end{array}$ & Agree & $\begin{array}{c}\text { No } \\
\text { Opinion }\end{array}$ & $\begin{array}{c}\text { Dis- } \\
\text { Agree }\end{array}$ & $\begin{array}{c}\text { Strongly } \\
\text { Dis-Agree }\end{array}$ \\
\hline$S 1$ & $\begin{array}{c}19 \\
(09.50)\end{array}$ & $\begin{array}{c}163 \\
(81.50)\end{array}$ & $\begin{array}{c}10 \\
(5.00)\end{array}$ & $\begin{array}{c}08 \\
(04.00)\end{array}$ & $\begin{array}{c}00 \\
(00.00)\end{array}$ \\
\hline$S 2$ & $\begin{array}{c}32 \\
(16.00)\end{array}$ & $\begin{array}{c}129 \\
(64.50)\end{array}$ & $\begin{array}{c}32 \\
(16.00)\end{array}$ & $\begin{array}{c}07 \\
(03.50)\end{array}$ & $\begin{array}{c}00 \\
(00.00)\end{array}$ \\
\hline$S 3$ & $\begin{array}{c}34 \\
(17.00)\end{array}$ & $\begin{array}{c}110 \\
(55.00)\end{array}$ & $\begin{array}{c}51 \\
(25.50)\end{array}$ & $\begin{array}{c}05 \\
(02.50)\end{array}$ & $\begin{array}{c}00 \\
(00.00)\end{array}$ \\
\hline$S 4$ & $\begin{array}{c}23 \\
(11.50)\end{array}$ & $\begin{array}{c}114 \\
(57.00)\end{array}$ & $\begin{array}{c}48 \\
(24.00)\end{array}$ & $\begin{array}{c}15 \\
(7.50)\end{array}$ & $\begin{array}{c}00 \\
(00.00)\end{array}$ \\
\hline$S 5$ & $\begin{array}{c}25 \\
(12.50)\end{array}$ & $\begin{array}{c}87 \\
(43.50)\end{array}$ & $\begin{array}{c}72 \\
(36.00)\end{array}$ & $\begin{array}{c}15 \\
(7.50)\end{array}$ & $\begin{array}{c}01 \\
(00.50)\end{array}$ \\
\hline S6 & $\begin{array}{c}15 \\
(07.50)\end{array}$ & \begin{tabular}{c|}
111 \\
$(55.50)$
\end{tabular} & $\begin{array}{c}45 \\
(22.50)\end{array}$ & $\begin{array}{c}22 \\
(11.00)\end{array}$ & $\begin{array}{c}07 \\
(03.50)\end{array}$ \\
\hline S7 & $\begin{array}{c}19 \\
(09.50)\end{array}$ & \begin{tabular}{|c|}
96 \\
$(48.00)$
\end{tabular} & $\begin{array}{c}51 \\
(25.50)\end{array}$ & $\begin{array}{c}30 \\
(15.00)\end{array}$ & $\begin{array}{c}04 \\
(02.00)\end{array}$ \\
\hline
\end{tabular}

Source: Primary Data 
From the Table.1, it is revealed that Majority of the respondents have agreed with the statements that, "they are influenced by advertisements", "advertisements are providing knowledge about products and services", "advertisements provides detailed information about the products and services", "advertising helps to suggest the products to others", "advertising acts as an identification of products and services", "advertising creates trust about the products and services" and "advertising maintains quality of goods".

\subsubsection{Opinion Regarding Advertising - Application of Factor Analysis:}

Opinion of the respondents towards the advertising has been analyzed and the result is presented in the Table.2.

Table.2. Advertising

\begin{tabular}{|c|c|c|}
\hline Statements & $\begin{array}{c}\text { Factor } \\
\text { Loading }\end{array}$ & $\begin{array}{c}\text { Communality } \\
\mathbf{( h}^{\mathbf{2}} \mathbf{)}\end{array}$ \\
\hline $\begin{array}{c}\text { Advertising helps me to suggest the } \\
\text { products to others (S4) }\end{array}$ & 0.840 & 0.705 \\
\hline $\begin{array}{c}\text { Advertisements provides detailed } \\
\text { information about the products and } \\
\text { services (S3) }\end{array}$ & 0.791 & 0.625 \\
\hline $\begin{array}{c}\text { Advertising acts as an identification } \\
\text { of the products and services (S5) }\end{array}$ & 0.732 & 0.536 \\
\hline $\begin{array}{c}\text { Advertising creates a trust about the } \\
\text { products and services (S6) }\end{array}$ & 0.722 & 0.521 \\
\hline $\begin{array}{c}\text { Advertisements helps in acquiring } \\
\text { knowledge about the products and } \\
\text { services (S2) }\end{array}$ & 0.689 & 0.475 \\
\hline $\begin{array}{c}\text { I am influenced by the } \\
\text { advertisements (S1) }\end{array}$ & 0.672 & 0.451 \\
\hline $\begin{array}{c}\text { Advertising maintains quality of } \\
\text { goods (S7) }\end{array}$ & 0.662 & 0.438 \\
\hline
\end{tabular}

Source: Computed Primary Data

All the statements regarding advertising are loaded with the factor value of more than 0.5 . Hence all the variables are taken into account. Out of the seven variables, "Advertising helps me to suggest the products to others" and "Advertisements provides detailed information about the products and services" are having high factor loading of more than 0.75 , hence considered to be important.

\subsubsection{Opinion Regarding Sales Promotion:}

Sales promotion helps in promoting the customers to use the products and services of the bank. The researcher gathered details about the opinion of the customers towards the sales promotions given by the banks which is interpreted in the Table.3.

Table.3. Opinion Regarding Advertising

\begin{tabular}{|c|c|c|c|c|c|}
\hline Statements & $\begin{array}{c}\text { Strongly } \\
\text { Agree }\end{array}$ & Agree & $\begin{array}{c}\text { No } \\
\text { Opinion }\end{array}$ & $\begin{array}{c}\text { Dis- } \\
\text { Agree }\end{array}$ & $\begin{array}{c}\text { Strongly } \\
\text { Dis-Agree }\end{array}$ \\
\hline $\boldsymbol{S 1}$ & 22 & $\mathbf{9 9}$ & 64 & 13 & 02 \\
$(11.00)$ & $\mathbf{( 4 9 . 5 0 )}$ & $(32.00)$ & $(6.50)$ & $(01.00)$ \\
\hline $\boldsymbol{S} \mathbf{2}$ & 23 & $\mathbf{8 5}$ & 67 & 20 & 05 \\
\hline
\end{tabular}

\begin{tabular}{|c|c|c|c|c|c|}
\hline & $(11.50)$ & $\mathbf{( 4 2 . 5 0 )}$ & $(33.50)$ & $(10.00)$ & $(02.50)$ \\
\hline \multirow{2}{*}{ S3 } & 35 & $\mathbf{7 8}$ & 58 & 27 & 02 \\
& $(17.50)$ & $\mathbf{( 3 9 . 0 0 )}$ & $(29.00)$ & $(13.50)$ & $(01.00)$ \\
\hline \multirow{2}{*}{$S 4$} & 28 & $\mathbf{9 0}$ & 60 & 15 & 07 \\
& $(14.00)$ & $\mathbf{( 4 5 . 0 0})$ & $(30.00)$ & $(7.50)$ & $(03.50)$ \\
\hline \multirow{2}{*}{ S5 } & 23 & $\mathbf{8 6}$ & 67 & 17 & 07 \\
& $(11.50)$ & $\mathbf{( 4 3 . 0 0})$ & $(33.50)$ & $(08.50)$ & $(03.50)$ \\
\hline \multirow{2}{*}{ S6 } & 24 & $\mathbf{9 3}$ & 70 & 10 & 03 \\
& $(12.00)$ & $\mathbf{( 4 6 . 5 0 )}$ & $(35.00)$ & $(05.00)$ & $(01.50)$ \\
\hline \multirow{2}{*}{ S7 } & 30 & $\mathbf{8 8}$ & 50 & 26 & 06 \\
& $(15.00)$ & $\mathbf{( 4 4 . 0 0}$ & $(25.00)$ & $(13.00)$ & $(03.00)$ \\
\hline
\end{tabular}

Source: Primary Data

From Table.3, it is revealed that 99 respondents (49.50\%) have agreed with the statement that "Pamphlets and notices gives awareness about the services offered", 85 respondents $(42.50 \%)$ have agreed with the statement that "Sales Promotion helps in attracting the customers", 78 respondents (39.00\%) have agreed with the statement that "Sales promotion helps in comparing the products and services offered", 90 respondents $(45.00 \%)$ have agreed with the statement that "Sales promotion creates differentiation", 86 respondents $(43.00 \%)$ have agreed with the statement that "Sales promotion helps in driving decision making", 93 respondents $(46.50 \%)$ have agreed with the statement that "Sales promotion influences to utilize the product or service" and 88 respondents $(44.00 \%)$ have agreed with the statement that "Sales promotion builds some sort of communication".

\subsubsection{Opinion Regarding Sales Promotion - Application of Factor Analysis:}

In order to determine the opinion regarding sales promotion, the researcher has used the factor analysis with the help of SPSS. The result is presented in the Table.4.

Table.4. Sales Promotion

\begin{tabular}{|c|c|c|}
\hline Statements & $\begin{array}{c}\text { Factor } \\
\text { Loading }\end{array}$ & $\begin{array}{c}\text { Communality } \\
\left(\mathbf{h}^{\mathbf{2}} \mathbf{)}\right.\end{array}$ \\
\hline $\begin{array}{c}\text { Sales Promotion creates } \\
\text { differentiation (S4) }\end{array}$ & 0.810 & 0.656 \\
\hline $\begin{array}{c}\text { Sales Promotion helps in driving } \\
\text { decision making (S5) }\end{array}$ & 0.797 & 0.635 \\
\hline $\begin{array}{c}\text { Sales Promotion influences to } \\
\text { utilize the product or service (S6) }\end{array}$ & 0.768 & 0.590 \\
\hline $\begin{array}{c}\text { Sales promotions builds some sort } \\
\text { of communication (S7) }\end{array}$ & 0.760 & 0.577 \\
\hline $\begin{array}{c}\text { Helps in comparing the products } \\
\text { and services (S3) }\end{array}$ & 0.753 & 0.567 \\
\hline $\begin{array}{c}\text { Sales Promotion helps in attracting } \\
\text { the customers (S2) }\end{array}$ & 0.736 & 0.542 \\
\hline $\begin{array}{c}\text { Pamphlets and notices gives } \\
\text { awareness about the services } \\
\text { offered (S1) }\end{array}$ & 0.727 & 0.528 \\
\hline
\end{tabular}

Source: Computed Primary Data

For sales promotion, here seven statements are considered. To know the importance of the statements towards sales promotion, 
factor scores are taken into account. All the statements have factor loading more than the acceptable level of 0.5. Moreover the statements serial numbered 1, 2, 3, 4 and 5 are having factor loading more than 0.75 which indicates these statements have predict more the sales promotion.

\subsubsection{Opinion Regarding Direct Marketing:}

Direct marketing is an important that attracts the customers of the bank. Opinions of the respondents about the direct marketing services are listed in the Table.5.

Table.5. Opinion Regarding Direct Marketing

\begin{tabular}{|c|c|c|c|c|c|}
\hline Statements & $\begin{array}{c}\text { Strongly } \\
\text { Agree }\end{array}$ & Agree & $\begin{array}{c}\text { No } \\
\text { Opinion }\end{array}$ & $\begin{array}{c}\text { Dis- } \\
\text { Agree }\end{array}$ & $\begin{array}{c}\text { Strongly } \\
\text { Dis-Agree }\end{array}$ \\
\hline$S 1$ & $\begin{array}{c}14 \\
(7.00) \\
\end{array}$ & \begin{tabular}{|c|}
93 \\
$(46.50)$ \\
\end{tabular} & $\begin{array}{c}70 \\
(35.00) \\
\end{array}$ & $\begin{array}{c}17 \\
(8.50) \\
\end{array}$ & $\begin{array}{c}06 \\
(03.00) \\
\end{array}$ \\
\hline$S 2$ & $\begin{array}{c}20 \\
(10.00)\end{array}$ & $\begin{array}{c}85 \\
(42.50)\end{array}$ & $\begin{array}{c}67 \\
(33.50)\end{array}$ & $\begin{array}{c}26 \\
(13.00)\end{array}$ & $\begin{array}{c}02 \\
(01.00)\end{array}$ \\
\hline$S 3$ & $\begin{array}{c}22 \\
(11.00)\end{array}$ & $\begin{array}{c}90 \\
(45.00)\end{array}$ & $\begin{array}{c}62 \\
(31.00)\end{array}$ & $\begin{array}{c}22 \\
(11.00)\end{array}$ & $\begin{array}{c}04 \\
(02.00)\end{array}$ \\
\hline$S 4$ & $\begin{array}{c}26 \\
(13.00) \\
\end{array}$ & $\begin{array}{c}72 \\
(36.00) \\
\end{array}$ & $\begin{array}{c}79 \\
(39.50)\end{array}$ & $\begin{array}{c}23 \\
(11.50) \\
\end{array}$ & $\begin{array}{c}00 \\
(00.00)\end{array}$ \\
\hline$S 5$ & $\begin{array}{c}11 \\
(05.50)\end{array}$ & $\begin{array}{c}73 \\
(36.50)\end{array}$ & $\begin{array}{c}76 \\
(38.00)\end{array}$ & $\begin{array}{c}28 \\
(14.00)\end{array}$ & $\begin{array}{c}12 \\
(06.00)\end{array}$ \\
\hline S6 & $\begin{array}{c}12 \\
(06.00)\end{array}$ & $\begin{array}{c}65 \\
(32.50) \\
\end{array}$ & $\begin{array}{c}91 \\
(45.50)\end{array}$ & $\begin{array}{c}27 \\
(13.50) \\
\end{array}$ & $\begin{array}{c}05 \\
(02.50) \\
\end{array}$ \\
\hline S7 & $\begin{array}{c}14 \\
(07.00)\end{array}$ & $\begin{array}{c}82 \\
(41.00)\end{array}$ & $\begin{array}{c}79 \\
(39.50)\end{array}$ & $\begin{array}{c}21 \\
(10.50)\end{array}$ & $\begin{array}{c}04 \\
(02.00)\end{array}$ \\
\hline
\end{tabular}

The Table. 5 shows that, Most of the respondents have agreed with the statements that "E-mails and messages helps the customers to know about the services", "New products introduced will be first made known to the existing customers", "Direct marketing builds personal connections" and "Direct marketing creates a good image". Most of the respondents have no opinion with the statements that "direct marketing helps in providing direct feedback", "direct marketing helps in having awareness about new products" and direct marketing creates loyalty".

\subsubsection{Opinion Regarding Direct Marketing - Application of Factor Analysis:}

The researcher has used the factor analysis to analyze the opinion regarding direct marketing with the help of SPSS. The result is presented in the Table.6.

Table.6. Direct Marketing

\begin{tabular}{|c|c|c|}
\hline Statements & $\begin{array}{c}\text { Factor } \\
\text { Loading }\end{array}$ & $\begin{array}{c}\text { Communality } \\
\left.\mathbf{( h}^{\mathbf{2}}\right)\end{array}$ \\
\hline $\begin{array}{c}\text { Direct Marketing helps in having } \\
\text { awareness about new products (S5) }\end{array}$ & 0.766 & 0.587 \\
\hline $\begin{array}{c}\text { Direct Marketing builds personal } \\
\text { connections (S3) }\end{array}$ & 0.737 & 0.543 \\
\hline $\begin{array}{c}\text { Direct Marketing helps in providing } \\
\text { direct feedback (S4) }\end{array}$ & 0.737 & 0.543 \\
\hline
\end{tabular}

\begin{tabular}{|c|c|c|}
\hline $\begin{array}{c}\text { E-mails and messages helps the } \\
\text { customers to know about the } \\
\text { services (S1) }\end{array}$ & 0.723 & 0.523 \\
\hline $\begin{array}{c}\text { Direct Marketing creates loyalty } \\
\text { (S6) }\end{array}$ & 0.703 & 0.494 \\
\hline $\begin{array}{c}\text { Direct Marketing creates a Good } \\
\text { Image (S7) }\end{array}$ & 0.699 & 0.488 \\
\hline $\begin{array}{c}\text { New Products introduced will be } \\
\text { first made known to the existing } \\
\text { customers (S2) }\end{array}$ & 0.641 & 0.412 \\
\hline
\end{tabular}

Source: Computed Primary Data

The Table. 6 reveals that, all the variables are loaded with more than 0.5 factor loading. And the variable "Direct Marketing helps in having awareness about new products" is loaded with 0.766 factor values, therefore it is considered to be very important.

\subsubsection{Opinion Regarding Personal Selling:}

The Table.7 gives the details about the opinion of the respondents towards the personal selling.

Table.7. Opinion Regarding Personal Selling

\begin{tabular}{|c|c|c|c|c|c|}
\hline Statements & $\begin{array}{c}\text { Strongly } \\
\text { Agree }\end{array}$ & Agree & $\begin{array}{c}\text { No } \\
\text { Opinion }\end{array}$ & $\begin{array}{c}\text { Dis- } \\
\text { Agree }\end{array}$ & $\begin{array}{l}\text { Strongly } \\
\text { Dis-Agree }\end{array}$ \\
\hline$S 1$ & $\begin{array}{c}14 \\
(7.00)\end{array}$ & $\begin{array}{c}98 \\
(49.00)\end{array}$ & $\begin{array}{c}72 \\
(36.00)\end{array}$ & $\begin{array}{c}10 \\
(5.00)\end{array}$ & $\begin{array}{c}06 \\
(03.00)\end{array}$ \\
\hline$S 2$ & $\begin{array}{c}23 \\
(11.50) \\
\end{array}$ & $\begin{array}{c}103 \\
(51.50)\end{array}$ & $\begin{array}{c}48 \\
(24.00) \\
\end{array}$ & $\begin{array}{c}23 \\
(11.50) \\
\end{array}$ & $\begin{array}{c}03 \\
(01.50) \\
\end{array}$ \\
\hline$S 3$ & $\begin{array}{c}29 \\
(14.50)\end{array}$ & $\begin{array}{c}93 \\
(46.50)\end{array}$ & $\begin{array}{c}50 \\
(25.00)\end{array}$ & $\begin{array}{c}24 \\
(12.00)\end{array}$ & $\begin{array}{c}04 \\
(02.00)\end{array}$ \\
\hline$S 4$ & $\begin{array}{c}17 \\
(08.50)\end{array}$ & $\begin{array}{c}86 \\
(43.00)\end{array}$ & $\begin{array}{c}60 \\
(30.00)\end{array}$ & $\begin{array}{c}31 \\
(15.50)\end{array}$ & $\begin{array}{c}06 \\
(03.00)\end{array}$ \\
\hline$S 5$ & $\begin{array}{c}17 \\
(08.50)\end{array}$ & $\begin{array}{c}65 \\
(32.50)\end{array}$ & $\begin{array}{c}93 \\
(46.50)\end{array}$ & $\begin{array}{c}23 \\
(11.50)\end{array}$ & $\begin{array}{c}02 \\
(01.00)\end{array}$ \\
\hline S6 & $\begin{array}{c}23 \\
(11.50) \\
\end{array}$ & $\begin{array}{c}60 \\
(30.00) \\
\end{array}$ & $\begin{array}{c}69 \\
(34.50) \\
\end{array}$ & $\begin{array}{c}41 \\
(20.50) \\
\end{array}$ & $\begin{array}{c}07 \\
(03.50) \\
\end{array}$ \\
\hline S7 & $\begin{array}{c}22 \\
(11.00)\end{array}$ & $\begin{array}{c}80 \\
(40.00)\end{array}$ & $\begin{array}{c}71 \\
(35.50)\end{array}$ & $\begin{array}{c}19 \\
(9.50)\end{array}$ & $\begin{array}{c}08 \\
(04.00)\end{array}$ \\
\hline$S 8$ & $\begin{array}{c}19 \\
(09.50)\end{array}$ & $\begin{array}{c}73 \\
(36.50)\end{array}$ & $\begin{array}{c}74 \\
(37.00)\end{array}$ & $\begin{array}{c}25 \\
(12.50)\end{array}$ & $\begin{array}{c}09 \\
(04.50)\end{array}$ \\
\hline
\end{tabular}

Source: Primary Data

From Table.7, it is revealed that 98 respondents $(49.00 \%)$ have agreed with the statement that "Personal Selling influences the customers to use the products", 103 respondents $(51.50 \%)$ have agreed with the statement that "Personal Selling helps in clarifying doubts", 93 respondents $(46.50 \%)$ have agreed with the statement that "Personal selling is highly interactive", 86 respondents $(43.00 \%)$ have agreed with the statement that "Personal Selling creates a good relationship", 93 respondents $(46.50 \%)$ have no opinion with the statement that "Personal Selling helps in creating loyalty", 69 respondents (34.50\%) have no opinion with the statement that "Personal selling creates personal attention", 80 respondents $(40.00 \%)$ have agreed with the statement that "Personal Selling gives detailed demonstration" and 74 respondents $(37.00 \%)$ have no opinion with the statement "Personal selling creates customer confidence". 


\subsubsection{Opinion Regarding Personal Selling - Application of Factor Analysis:}

In order to analyze the opinion regarding personal selling, the researcher has used the factor analysis with the help of SPSS. The result is presented in the Table.8.

Table.8. Personal Selling

\begin{tabular}{|c|c|c|}
\hline Statements & $\begin{array}{c}\text { Factor } \\
\text { Loading }\end{array}$ & $\begin{array}{c}\text { Communality } \\
\left(\mathbf{h}^{\mathbf{2}}\right)\end{array}$ \\
\hline $\begin{array}{c}\text { Personal selling creates Personal } \\
\text { attention }\end{array}$ & 0.784 & 0.615 \\
\hline $\begin{array}{c}\text { Personal selling gives Detailed } \\
\text { Demonstration }\end{array}$ & 0.732 & 0.536 \\
\hline $\begin{array}{c}\text { Personal selling creates customer } \\
\text { confidence }\end{array}$ & 0.730 & 0.533 \\
\hline $\begin{array}{c}\text { Helps in clarifying the doubts regarding } \\
\text { the products }\end{array}$ & 0.706 & 0.498 \\
\hline Personal selling its highly interactive & 0.705 & 0.497 \\
\hline $\begin{array}{c}\text { Personal selling influences the } \\
\text { customers to use the products }\end{array}$ & 0.687 & 0.472 \\
\hline $\begin{array}{c}\text { Personal selling creates a good } \\
\text { relationship }\end{array}$ & 0.686 & 0.470 \\
\hline Personal selling helps in creates loyalty & 0.635 & 0.403 \\
\hline
\end{tabular}

Source: Computed Primary Data

The Table. 8 reveals that, personal selling, here seven statements are considered. To know the importance of the statements towards personal selling, factor scores are taken into account. All the statements have factor loading more than the acceptable level of 0.5. Moreover the statement "Personal selling creates personal attention" is having factor loading more than 0.75 . Hence it may have a greater impact over personal selling.

\subsubsection{Opinion Regarding Public Relations:}

The researcher has analyzed the opinion regarding public relations. The result is presented in the Table.9.

Table.9. Opinion Regarding Public Relations

\begin{tabular}{|c|c|c|c|c|c|}
\hline Statements & $\begin{array}{c}\text { Strongly } \\
\text { Agree }\end{array}$ & Agree & $\begin{array}{c}\text { No } \\
\text { Opinion }\end{array}$ & $\begin{array}{c}\text { Dis- } \\
\text { Agree }\end{array}$ & $\begin{array}{c}\text { Strongly } \\
\text { Dis-Agree }\end{array}$ \\
\hline \multirow{2}{*}{$\boldsymbol{S 1}$} & $\begin{array}{c}21 \\
(10.50)\end{array}$ & $\begin{array}{c}69 \\
(34.50)\end{array}$ & $\begin{array}{c}\mathbf{8 1} \\
\mathbf{( 4 0 . 5 0 )}\end{array}$ & $\begin{array}{c}29 \\
(14.50)\end{array}$ & $\begin{array}{c}00 \\
(00.00)\end{array}$ \\
\hline \multirow{2}{*}{$\boldsymbol{S} \mathbf{2}$} & 31 & 60 & $\mathbf{8 4}$ & 19 & 06 \\
& $(15.50)$ & $(30.00)$ & $\mathbf{( 4 2 . 0 0 )}$ & $(09.50)$ & $(03.00)$ \\
\hline \multirow{2}{*}{$\boldsymbol{S 3}$} & 22 & 69 & $\mathbf{7 0}$ & 32 & 07 \\
& $(11.00)$ & $(34.50)$ & $\mathbf{( 3 5 . 0 0 )}$ & $(16.00)$ & $(03.50)$ \\
\hline \multirow{2}{*}{$\boldsymbol{S 4}$} & 30 & 53 & $\mathbf{8 5}$ & 24 & 08 \\
& $(15.00)$ & $(26.50)$ & $\mathbf{( 4 2 . 5 0 )}$ & $(12.00)$ & $(04.00)$ \\
\hline \multirow{2}{*}{$\boldsymbol{S 5}$} & 20 & 61 & $\mathbf{9 1}$ & 19 & 09 \\
& $(10.00)$ & $(30.50)$ & $\mathbf{( 4 5 . 5 0 )}$ & $(09.50)$ & $(04.50)$ \\
\hline \multirow{2}{*}{$\boldsymbol{S 6}$} & 27 & $\mathbf{1 1 3}$ & 40 & 18 & 02 \\
& $(13.50)$ & $(\mathbf{5 6 . 5 0})$ & $(20.00)$ & $(09.00)$ & $(01.00)$ \\
\hline \multirow{2}{*}{$\boldsymbol{S 7}$} & 23 & $\mathbf{1 1 4}$ & 37 & 16 & 10 \\
& $(11.50)$ & $(\mathbf{5 7 . 0 0})$ & $(18.50)$ & $(8.00)$ & $(05.00)$ \\
\hline
\end{tabular}

\begin{tabular}{|c|c|c|c|c|c|}
\hline \multirow{S}{S}{$\boldsymbol{8}$} & $\begin{array}{c}27 \\
(13.50)\end{array}$ & $\begin{array}{c}\mathbf{9 8} \\
\mathbf{4 9 . 0 0})\end{array}$ & $\begin{array}{c}47 \\
(23.50)\end{array}$ & $\begin{array}{c}25 \\
(12.50)\end{array}$ & $\begin{array}{c}03 \\
(01.50)\end{array}$ \\
\hline \multirow{2}{*}{$\boldsymbol{S 9}$} & 34 & 44 & 55 & $\mathbf{5 8}$ & 09 \\
& $(17.00)$ & $(22.00)$ & $(27.50)$ & $(\mathbf{2 9 . 0 0 )}$ & $(04.50)$ \\
\hline \multirow{2}{*}{$\boldsymbol{S 1 0}$} & 24 & 58 & $\mathbf{6 3}$ & 45 & 10 \\
& $(12.00)$ & $(29.00)$ & $\mathbf{( 3 1 . 5 0 )}$ & $(22.50)$ & $(05.00)$ \\
\hline \multirow{2}{*}{$\boldsymbol{S 1 1}$} & 32 & 31 & $\mathbf{6 9}$ & 53 & 15 \\
& $(16.00)$ & $(15.50)$ & $\mathbf{( 3 4 . 5 0 )}$ & $(26.50)$ & $(07.50)$ \\
\hline \multirow{2}{*}{$\boldsymbol{S 1 2}$} & 29 & 34 & $\mathbf{6 3}$ & 61 & 13 \\
& $(14.50)$ & $(17.00)$ & $\mathbf{( 3 1 . 5 0 )}$ & $(30.50)$ & $(06.50)$ \\
\hline \multirow{2}{*}{$\boldsymbol{S 1 3}$} & 44 & $\mathbf{8 7}$ & 46 & 19 & 04 \\
& $(22.00)$ & $\mathbf{( 4 3 . 5 0 )}$ & $(23.00)$ & $(09.50)$ & $(02.00)$ \\
\hline
\end{tabular}

Source: Primary Data

The Table. 9 reveals that out of 200 respondents, Most of the respondents have No opinion with the statements serial numbered $1,2,3,4,5,10,11$ and 12, Majority of the respondents have agreed with the statement serial numbered 6, 7, 8 and 13 and Most of the respondents have disagreed with the statement serial numbered 9.

\subsubsection{Opinion Regarding Public Relations - Application of Factor Analysis:}

Factor analysis tool has been used to analyse the opinion of the respondents towards the public relations. The Table.10 shows the results of the analysis.

Table.8. Personal Selling

\begin{tabular}{|c|c|c|}
\hline Statements & $\begin{array}{c}\text { Factor } \\
\text { Loading }\end{array}$ & $\begin{array}{c}\text { Communality } \\
\left(h^{2}\right)\end{array}$ \\
\hline $\begin{array}{l}\text { Payment of taxes correctly creates the } \\
\text { goodwill (S11) }\end{array}$ & 0.855 & 0.731 \\
\hline $\begin{array}{l}\text { Spread the brand by running } \\
\text { educational institutions (S9) }\end{array}$ & 0.811 & 0.658 \\
\hline $\begin{array}{l}\text { Making socially liable gives perpetual } \\
\text { life (S12) }\end{array}$ & 0.810 & 0.656 \\
\hline $\begin{array}{l}\text { I am Loyal to the bank because of its } \\
\text { CSR activities of the bank (S2) }\end{array}$ & 0.798 & 0.637 \\
\hline $\begin{array}{l}\text { Familiarize the brand through } \\
\text { undertaking social services (S5) }\end{array}$ & 0.786 & 0.618 \\
\hline $\begin{array}{l}\text { I am attracted towards the bank } \\
\text { because of its brand image (S3) }\end{array}$ & 0.765 & 0.586 \\
\hline I am influenced by the relationship (S4) & 0.753 & 0.568 \\
\hline $\begin{array}{l}\text { Submission of records promptly to } \\
\text { government maker the bank } \\
\text { government friendly (S10) }\end{array}$ & 0.751 & 0.564 \\
\hline $\begin{array}{l}\text { I always support the scholarship and } \\
\text { other facilities for education by bank } \\
\text { (S8) }\end{array}$ & 0.702 & 0.492 \\
\hline $\begin{array}{l}\text { Expand their operation through their } \\
\text { social participation (S1) }\end{array}$ & 0.677 & 0.458 \\
\hline $\begin{array}{l}\text { I am attracted when the bank join } \\
\text { hands with natural calamities (S7) }\end{array}$ & 0.670 & 0.448 \\
\hline $\begin{array}{c}\text { To be closer to the public by donation } \\
\text { and gifts (S6) }\end{array}$ & 0.643 & 0.413 \\
\hline
\end{tabular}

Source: Computed Primary Data 
The Table.10 shows that the public relations variables are having factor loading of more than 0.5 , hence all the statements are considered for the further analysis.

Out of the 12 statements, 8 variables are considered to be important that have more than 0.75 factor value.

\subsubsection{Consolidated Results and Interpretation for the Opinion of Customers towards Sources of Penetration:}

The statements which influence the opinion of customers towards sources of penetration are discussed in Table.11.

Table.11. Statements with the Highest Factor Loadings for the Opinion of Customers towards Sources of Penetration

\begin{tabular}{|c|c|c|}
\hline $\begin{array}{c}\text { Name of the } \\
\text { Sources }\end{array}$ & Statement & $\begin{array}{c}\text { Factor } \\
\text { Loading }\end{array}$ \\
\hline Advertising & $\begin{array}{c}\text { Advertising helps me to suggest the } \\
\text { products to others }\end{array}$ & 0.840 \\
\hline $\begin{array}{c}\text { Sales } \\
\text { Promotion }\end{array}$ & Sales Promotions creates differentiation & 0.810 \\
\hline $\begin{array}{c}\text { Direct } \\
\text { Marketing }\end{array}$ & $\begin{array}{c}\text { Direct Marketing helps in having } \\
\text { awareness about new products }\end{array}$ & 0.766 \\
\hline $\begin{array}{c}\text { Personal } \\
\text { Selling }\end{array}$ & $\begin{array}{c}\text { Personal selling creates Personal } \\
\text { attention }\end{array}$ & 0.784 \\
\hline $\begin{array}{c}\text { Public } \\
\text { Relations }\end{array}$ & $\begin{array}{c}\text { Payment of taxes correctly creates the } \\
\text { goodwill }\end{array}$ & 0.855 \\
\hline \multicolumn{2}{|c|}{ Source: Computed Primary Data } \\
\hline
\end{tabular}

It is apparent from Table.11 that the statement, Advertising helps me to suggest the products to others with factor loading 0.840 , Promotions creates differentiation with factor loading 0.810 , Helps in having awareness about new products with factor loading 0.766, Personal attention with factor loading 0.784 , Payment of taxes correctly creates the goodwill with factor loading 0.855 are the statements with highest factor loadings under the dimensions namely Advertising, Sales Promotions, Direct Marketing, Personal Selling, Public Relations respectively. Hence, these are identified dimensions (variables), which influence the Sources of penetration.

\subsection{IDENTIFICATION OF PENETRATION LEVEL}

The researcher has computed the level of penetration by the scores values of 36 statements adopted through likert five point scaling techniques. The total score values are divided into two levels that is low level and high level. The result is presented in Table.12.

Table.12. Level of Penetration

\begin{tabular}{|c|c|c|}
\hline S.No & Level & No. of Respondents (Percentage) \\
\hline 1 & High & $51(25.50)$ \\
\hline 2 & Low & $149(74.50)$ \\
\hline \multicolumn{2}{|c|}{ Total } & $\mathbf{2 0 0}(\mathbf{1 0 0 . 0 0})$ \\
\hline
\end{tabular}

Source: Computed Data

Note: As already reported in our earlier article [20].

\subsection{SOURCES OF PENETRATION AND LEVEL OF PENETRATION - APPLICATION OF DISCRIMINANT ANALYSIS}

The researcher has applied the discriminant analysis to find which factor absolutely predicts level of penetration. For that purpose the factor analysis has been applied and the factor scores are treated as dependent variable in discriminant analysis. A rule of thumb the independent variable should be nominal or ordinal scale with the (two) distinct parameter. So, the scale statement recorded with two factors namely low penetrated and high penetrated.

In discriminant analysis, the researcher should first analyze the Wilks' Lambda test for valid of the model. Wilks' lambda test is a test, which identifies whether the variables contribute significantly to discriminant function, if the Wilks' lambda value is closer to zero the model is more contributed by the variable. The test also explains the group membership through Chi-Square test. If the P-value is less than 0.05 , it concludes the corresponding function explains the group membership well. Table.13 shows the Chi-Square and Wilks' Lambda values.

Table.13. Wilks' Lambda

\begin{tabular}{|c|c|c|c|c|}
\hline Test of Function(s) & Wilks' Lambda & Chi-Square & Df & Sig. \\
\hline 1 & 0.814 & 40.242 & 5 & 0.000 \\
\hline
\end{tabular}

Source: Computed Primary Data

The Table.13 shows the significance of the discriminant model. The value of Wilks' Lambda is 0.814 that is, $81.4 \%$ of the variables not explained by the group differences. The Wilks' Lambda takes a value between 0 and 1 and lower the value of Wilks' lambda, the higher is the significance of the discriminant function. The statistical test of significance for Wilks' lambda is carried out with the chi-squared transformed statistic, which in our case is 40.242 with 5 degrees of freedom (degrees of freedom equals the number of predictor variables) and a $\mathrm{P}$ value is 0.000 which is less than the cutoff point 0.05 . Therefore, the researcher concludes that there is a relationship between dependent and independent variables. Hence the researcher further analyses the other tests for effectiveness of the model.

Table.14. Classification Results ${ }^{\mathrm{a}, \mathrm{b}, \mathrm{c}}$

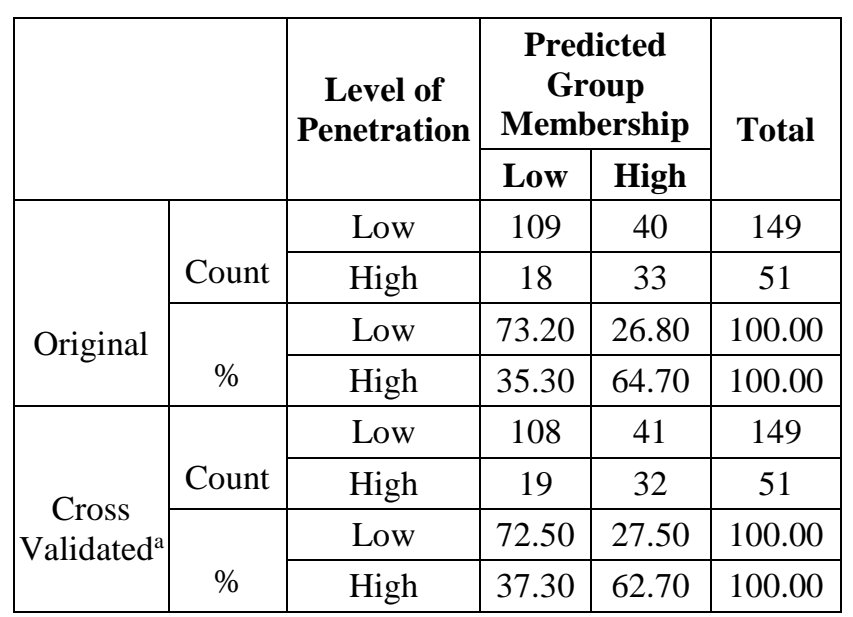


a - Cross validation is done only for those cases in the analysis. In case validation each case is classified by the functions derived from all cases other than that case.

b- $71.0 \%$ of original grouped cases correctly classified.

c $-70.0 \%$ of cross-validated grouped cases correctly classified.

The Table.14 shows the classification results of discriminant model. Overall $100 \%$ of the cases correctly classified in the model.

Eigen value is often cited in Discriminant function analysis. The Eigen values describe the effectiveness of discriminant function. Larger Eigen values indicate that the discriminant function is more useful in distinguishing the groups and canonical correlation indicates a function that discriminates well. The canonical correlation is the multiple correlations between the predictor and the discriminant function. With only one function it provides an index of overall model fit which is interpreted as being the proportion of variance explained $\left(\mathrm{R}^{2}\right)$. The Eigen values are presented in the Table.15.

Table.15. Eigen Values

\begin{tabular}{|c|c|c|c|c|}
\hline Function & $\begin{array}{c}\text { Eigen } \\
\text { Value }\end{array}$ & $\begin{array}{c}\text { \% of } \\
\text { Variance }\end{array}$ & $\begin{array}{c}\text { Cumulative } \\
\text { \% }\end{array}$ & $\begin{array}{c}\text { Canonical } \\
\text { Correlation }\end{array}$ \\
\hline 1 & $0.229^{\mathrm{a}}$ & 100.0 & 100.0 & 0.431 \\
\hline
\end{tabular}

Source: Computed Data

a - First 1 canonical discriminant functions were used in analysis.

The last column of Table.15 indicates canonical correlation, which is the simple correlation coefficient between the discriminant score and their corresponding group membership (Low Penetration). An Eigen Value indicates the proportion of variance explained. A large Eigen value is not associated with a strong function. A high correlation indicates a function that discriminates well. The present correlation is 0.431 , the square of the canonical correlation is $(0.431)^{2}=0.186$, which means $18.6 \%$ of the variance in the discriminating model between a prospective group low penetration is due to the changes in the five predictor variables, namely Advertising, Sales Promotion, Direct Marketing, Personal Selling and Public Relations.

The discriminant analysis resulted to find which factors absolutely predict level of penetration. From the analysis it is understood that only 18.6 percent of the variable predict the level of penetration.

The discriminant coefficient is exactly in the same way as a regression coefficient. This means that each coefficient reflects the relative contribution of each of the predictor variable on the discriminant function. A small value of the discriminant coefficient means that the impact of a unit change in a predictor variable is small in the discriminant function score. The Table.16 exhibits the Standardized Discriminant Function Coefficient.

Table.16. Standardized Discriminant Function Coefficient

\begin{tabular}{|c|c|}
\hline Sources & Function 1 \\
\hline Advertising & 0.588 \\
\hline Sales Promotion & -0.156 \\
\hline
\end{tabular}

\begin{tabular}{|c|c|}
\hline Direct Marketing & 0.399 \\
\hline Personal Selling & 0.196 \\
\hline Public Relations & 0.333 \\
\hline
\end{tabular}

Source: Computed Data

The Table.16 gives the standardized canonical discriminant function coefficients. It indicates that Advertising is the most important sources, which discriminates between the low penetration and high penetration, followed by Direct Marketing, Public Relations, Personal Selling and Sales Promotions.

Another way of finding the relative contributions of the predictor variables in discriminating between the low penetration and high penetration groups is through comparing the structural coefficients of the predictor variables. The structural coefficients are obtained by computing the correlation between the discriminant score and each of the independent variables. These are also called discriminant loadings. The structure matrix is presented in Table.17.

Table.17. Structure Matrix

\begin{tabular}{|l|c|}
\hline \multicolumn{1}{|c|}{ Sources } & Function 1 \\
\hline Direct Marketing & 0.828 \\
\hline Advertising & 0.737 \\
\hline Sales Promotion & 0.693 \\
\hline Personal Selling & 0.691 \\
\hline Public Relations & 0.631 \\
\hline
\end{tabular}

Source: Computed Data

The correlation coefficient between the discriminant score and the variable Direct Marketing is 0.828 , whereas the correlation with Advertising, Sales Promotion, Personal Selling and Public Relations is $0.737,0.693,0.691$ and 0.631 respectively. It is observed from Table.16 that Direct Marketing is the most important sources in discriminating between a low penetration and high penetration followed by Advertising, Sales Promotion, Personal Selling and Public Relations.

\section{FINDINGS OF THE STUDY}

The following are the important findings of the study:

- Majority of the respondents have agreed with the statements regarding Advertisement and Sales Promotion.

- Majority of the respondents have agreed for some statements and no opinion for the remaining statements regarding Direct Marketing.

- Majority of the respondents have agreed for some statements and no opinion for the remaining statements regarding Personal selling.

- Majority of the respondents have no opinion for some statements, agreed for statements and disagreed for the remaining statements regarding Public Relations.

- In Advertising, the statement "Advertising helps me to suggest the products to others" $(0.840)$ is the most dominating variable.

- In Sales Promotion, the statement "Promotions creates differentiation" $(0.810)$ is the most important variable out of the seven variables. 
- In Direct Marketing, the statement "Direct Marketing helps in having awareness about new products" $(0.766)$ is the most dominating variable.

- In Personal Selling, the statement "Personal selling creates Personal attention" $(0.784)$ is the most important variable.

- In Public Relations, the statement "Payment of taxes correctly creates the goodwill" (0.855) is the most dominating variable out of 13 variables.

- Sources of Penetration and Level of Penetration Application Discriminant Analysis. The result of Discriminant analysis reveals that only $18.6 \%$ of the variables predict the level of penetration especially Advertising and Direct Marketing are the most important sources that discriminates the level of penetration.

\section{CONCLUSION}

Based on the findings of the study, Advertising and Direct Marketing are the most influencing sources that penetrate the banking services to the rural people in the society. So, the researcher has suggested that the bank should more concentrate on Advertising and Direct Marketing at ever. On the other hand, Sales Promotion, Personal Selling and Public Relations are the sources of penetration which are not influencing the customers to the optimum level. Hence, the bank may give attention to the above stated promotional measures to more penetrate the services to more customers.

\section{ACKNOWLEDGEMENT}

Authors express their sense of thanks to the respectable management and energetic principal of their institution, for having endowed with an admirable infrastructure to seize the research and for publishing articles. We are extremely gratified to University Grant Commission for providing financial support of this research.

\section{REFERENCES}

[1] Shikha Sharma (2016), "Banking in India: 2016 and Beyond", Available

at: http://www.livemint.com/Opinion/RbCdGWKtAKfgyTDX YNEwvK/Banking-in-India-2016-and-beyond.html.

[2] Peter John, "Mobile Banking Products and Rural India: An Evaluation", IOSR Journal of Economics and Finance, Vol. 1, No. 5, pp. 36-40, 2013.

[3] N.S.N. Reddy, "Bank on Rural India-way to Economic Development", Available at: http://www.allbankingsolutions.com/Articles/ArticlesNSNR-Bank-on-Rural-India.htm.

[4] C.P. Mohan, "Marketing of Banking Services in Rural Areas", Available at: http://cab.org.in/Lists/Knowledge\%20Bank/DispForm.aspx ?ID=19

[5] Distribution of Financial Products in India, Available at: http://www.dnb.co.in/FESConfTool/Uploads\%5CDownloa ds $\% 5 C 100 \% 5$ CNotes $\% 20$ on $\% 20$ Distribution $\% 20$ of $\% 20 \mathrm{Fi}$ nancial\%20Products.pdf
[6] Puja Bansal and Vikas Behal, "Penetration of Scheduled Commercial Banks in Rural Areas: A Comparative Study", Indian Journal of Marketing, Vol. 7, No. 1, pp. 10-16, 2013.

[7] Anil Kumar Agarwal, "Banking Penetration in Rural Areas and Villages: Trends and Challenges", International Journal of Research in Commerce and Management, Vol. 6, No. 2, pp. 50-54, 2015.

[8] Neeraj Kumar and Anokhi, "An Overview of Rural Banking System", International Journal of Enhanced Research in Management and Computer Applications, Vol. 3, No. 8, pp. $1-4,2014$.

[9] Dhananjay Bapat, "Perceptions on Banking Service in Rural India: An Empirical Study", International Journal of Rural Management, Vol. 6, No. 2, pp. 303-321, 2010.

[10] M. Bhuvana and S. Vasantha, "Dimensions for Measuring Financial Inclusion in the Rural Areas of Tamil Nadu", Indian Journal of Science and Technology, Vol. 9, No. 32, pp. 1-8, 2016.

[11] Assocham India, "Logging into Digital Banking. Creating Access-Transforming Lives", Available at: https://www.pwc.in/assets/pdfs/publications/2015/logginginto-digital-banking.pdf

[12] India at No.4 in M-Banking Penetration, Available at: http://cio.economictimes.indiatimes.com/news/corporatenews/india-at-no-4-in-m-banking-penetration/48432318.

[13] BI Intelligence, "The digital disruption of retail banking-The Future of bank branch is in dire trouble", Available at: https://www.linkedin.com/digital-disruption-retail-bankingeasypay-al, Accessed on 2015.

[14] KPMG Report, "Mobile Banking" and "Global Trends and their impact on banks", Available at: http://emergingpayments.org/wpcontent/uploads/2017/02/KPMG-Mobile-Banking2015.pdf.

[15] J. Sethuraman, C. Vijayabanu and C. Therasa, "A Study on Channel Preferences among Urban and Rural Banking Customers", Indian Journal of Science and Technology, Vol. 9, No. 27, pp. 1-9, 2016.

[16] Apurva Singh, "E-banking in Suburban India", International Journal of Research in Management and Technology, Vol. 3, No. 6, pp. 189-198, 2013.

[17] Bhavesh J. Parmar, Darshan B. Ranpura, Chirag R. Patel and Naineshkumar P. Patel, "Rural Banking through Internet: A Study on Use of Internet Banking among Rural Consumers", Asian Journal of Management Research, Vol. 3, No. 2, pp. 325-335, 2013

[18] Cleland F. Afful, Jiri Hejkrlik and Tomas Doucha, "Rural Banking in Ghana and Its Impact on Rural Farmers. Case Study of the Birim South District, Ghana", Asian Social Science, Vol. 11, No. 25, pp. 101-110, 2015.

[19] Peter John, "Mobile Banking Products and Rural India: An Evaluation", IOSR Journal of Economics and Finance, Vol. 1, No. 5, pp. 36-40, 2013.

[20] M. Selvakumar, R. Mohammed Abubakkar Siddique and V. Sathyalakshmi, "The Level of Penetration of Banking Products and Services in the Rural Areas of Sivakasi: A Study of Customer Perception", The IUP Journal of Bank Management, Vol. 14, No. 2, pp. 29-52, 2017. 